\title{
UDC 541.64:678.7 \\ COPPER-CONTAINING NANOCOMPOSITES BASED ON ISOTACTIC POLYPROPYLENE AND HIGH PRESSURE POLYETHYLENE
}

\author{
S.K.Ragimova \\ Institute of Polymer Materials, NAS of Azerbaijan \\ sevinc.rehimova71@gmail.com
}

Received 22.05.2020

Accepted 14.12.2020

\begin{abstract}
The effect of nanofilles additives containing copper oxide nanoparticles stabilized by a polymer matrix of high-pressure polyethylene obtained by the mechanochemical method on features of the structure and properties of metal-containing nanocomposites based on isotactic polypropylene and high-pressure polyethylene was studied using differential thermal (DTA) and X-ray phase (XRD) analyzes. The improvement of strength, deformation and rheological parameters, as well as thermal-oxidative stability of the obtained nanocomposites was revealed, that apparently, is associated with the synergistic effect of interfacial interaction of copper-containing nanoparticles in the PE matrix with the components of the $\mathrm{PP} / \mathrm{PE}$ polymer composition.
\end{abstract}

Keywords: isotactic polypropylene; high pressure polyethylene, copper oxide nanoparticles, thermal properties, DTA and XRD analysis.

doi

\section{Introduction}

For the directed improvement of the properties of polypropylene (PP), the modification method is widely used, which consists in creation of polymer-polymer compositions [1].

Isotactic polypropylene (PP) and high pressure polyethylene (PE) are known to be immiscible polyolefins. To improve their compatibility existence functional groups in their composition or introduction of nanofillers (NF), which are an interphase additive, to the composition to improve both the compatibility of components and the operational properties of the obtained materials, is necessary [2-8].

The use of dispersed nanofillers allows one to control the structure and properties of materials due to nucleating and orientational effects, changes in the conformation of macromolecules, their chemical bonding to the surface of nanoparticles, and "healing" of structural defects $[9,10]$

The development of research on nanoscale and cluster metal-containing particles in polymer matrices was largely facilitated by the creation of metal-polymer composite materials with specific physico-[mechanical and operational properties: increased thermal and electrical conductivity, high magnetic susceptibility, the ability to shield ionizing radiation, etc. $[11,12]$.
It is known that the use of $d$-valence metal nanoparticles (copper, zinc, cobalt, nickel, etc.) in polymers allows one to obtain fundamentally new materials which are widely used in radio and optoelectronics as magnetic, electrically conductive, and optical media [12, 13].

The purpose of this work was to obtain and study the structure and properties of composites based on PP and PE with copper-containing nanofillers NF stabilized by a polymer matrix.

\section{Experimental part}

In the work were used: isotactic PP "Kaplen" (Russia) of brand 01030 with a molecular mass of $\sim(2-3) \cdot 10^{5}$, polydispersity index 4.5, MFI (2.3-3.6) g/10 min; High-pressure polyetilene (PE) of brand 15803-020 (Azerbaijan, SOCAR Polymer), $\rho=0.917-0.921 \mathrm{~g} / \mathrm{cm}$, MFI (1.5-2.5) g/10 min.

The nanoparticles (NP) of copper(I) oxides stabilized by a high-pressure polyethylene polymer matrix obtained by the mechanochemical method in a polymer melt were used as NF. The content of nanoparticles is 5 mass $\%$, size $25 \pm 1.0 \mathrm{~nm}$, crystallinity $35-45 \%$ [14, 15]. The ratio of the components of the composition (mass \%): $\mathrm{PP} / \mathrm{PE} / \mathrm{NF}=50 / 50 /(0.5,1.0,2.0)$.

Nanocomposite polymeric materials were obtained by mixing PE with copper-containing 
nanofillers on laboratory rollers at a temperature of $160-165^{\circ} \mathrm{C}$ for 15 minutes. For mechanical testing, the resulting mixtures were pressed in the form of plates $1 \mathrm{~mm}$ thick at $190^{\circ} \mathrm{C}$ and a pressure of $10 \mathrm{MPa}$ for 10 minutes.

Physical-mechanical parameters of the obtained compositions were determined on a RMI-250 device.

The melt flow index (MFI) was determined on a CEASTMF50 capillary rheometer from INSTRON, Italy, at a temperature of $190^{\circ} \mathrm{C}$ and a load of $5 \mathrm{~kg}$.

$\mathrm{X}$-ray phase analysis (XRD) of the obtained compositions was performed on a "D2 Phaser" instrument from Bruker, Germany.

The thermal stability of the studied samples of nanocomposites was studied on a Q$1500 \mathrm{D}$ derivatograph manufactured by MOM, Hungary. The tests were carried out in an atmosphere of air in a dynamic mode at a sample heating of $5 \mathrm{deg} / \mathrm{min}$ from 20 to $500^{\circ} \mathrm{C}, 100 \mathrm{mg}$ sample load, channel sensitivity DTA- $250 \mu \mathrm{V}$, TG-100, DTG-1 mV.

\section{Results and discussion}

Nanocomposite polymer materials based on PP/PE with a copper-containing nanofiller were obtained. Ratio of initial components (mass \%): $\mathrm{PP} / \mathrm{PE} / \mathrm{NF}=50 / 50 /(0,0.5,1.0,2.0)$.

The physical-mechanical, rheological, thermophysical and thermal properties of the obtained nanocomposites are studied.

Table 1 shows the physical, mechanical and rheological parameters of the obtained composite materials.

As can be seen from the data in Table 1, the introduction of $0.5-1.0$ mass $\%$ NF into the composition leads to an increase in the strength index from 13.15 to $16.87 \mathrm{MPa}$. An increasing the NF concentration of more than 1.0 mass \% leads to a decrease in the strength of the composite $(13.83 \mathrm{MPa})$, that is probably due to the aggregation of NP, that leads to the formation of microdefects in the bulk of the polymer matrix. The introduction of $0.5-1.0$ mass $\%$ NF into the composition leads to an increase in the strain at break of the composite by a factor of 1.2 , that is apparently connected with the synergistic effect of interfacial interaction of copper- containing nanoparticles in the PE matrix with the components of the polymer composition $\mathrm{PP} / \mathrm{PE}$ the mutual influence of which contributes to on increase in both the degree of deformation and the strength index.

A study of Vicat softening temperature of the obtained compositions showed that the introduction of a nanofiller into the composition of PP/PE practically does not affect the heat resistance index.

At the same time, an increase in the content of the nanofiller (1.0-2.0 mass \%) contributes to an increase of MFI to 18.5 (1.0 mass. \%) and 25.4 (2.0 mass.\%) g/10 min, that indicates an improvement in the fluidity of the composition and the possibility of processing it by injection molding and extrusion.

Figures 1 and 2 show the XRD patterns of the initial PP/PE and PP/PE with a coppercontaining nanofiller.

The reflexes corresponding to the initial $\mathrm{PP} / \mathrm{PE}$ are shown in Figure 1 and the reflexes characteristic of copper-containing nanoparticles: $d_{h k l} 3.02053,2.46466,2.13683,1.74331,1.51025$, $1.28812 \AA$ (Figure 2), which corresponds to the ASTM $\mathrm{d}_{h k l}$ series of copper oxide(I). [d-Spacing (20) - 01-071-3645 (Fixed Slit Intensity) - $\mathrm{CuK}_{\alpha 1}$ 1.54056 Å. Entry Date: 11/19/2008 Last Modification Date: 01/19/2011].

The thermal stability of the studied samples based on PE containing NF with NP of copper oxide was estimated by the value of mass loss, activation energy $\left(\mathrm{E}_{\mathrm{a}}\right)$ of thermaloxidative degradation, calculated by double logarithming of the TGA curve according to the method [16], by the temperature of $10 \%\left(T_{10}\right)$, $20 \%\left(T_{20}\right)$ and $50 \%\left(T_{50}\right)$ of the decay of the studied samples, as well as by their half-life time $-\mathrm{T}_{1 / 2}$. The data obtained as a result of derivatographic studies are shown in Table 2.

It is shown that the introduction of NF containing NP of copper oxide into the composition contributes to an increase in the half-life temperature of samples: $T_{50}$ from 325 to $390^{\circ} \mathrm{C}$; the half-life time $t_{1 / 2}$, increases from 55.6 to 74.8 min., the activation energy $\left(E_{\mathrm{a}}\right)$ of the thermal-oxidative degradation of the obtained nanocomposites increases from 191.4 to 248.9 $\mathrm{kJ} / \mathrm{mol}$. 
Table 1. Physico-mechanical and rheological parameters of the obtained nanocomposites

\begin{tabular}{|c|c|c|c|c|}
\hline $\begin{array}{c}\text { Composition (mass. \%) } \\
\text { PP/PE/NF }\end{array}$ & $\begin{array}{c}\text { Breaking strength, } \\
\mathrm{MPa}\end{array}$ & $\begin{array}{c}\text { Specific elongation, } \\
\%\end{array}$ & $\begin{array}{c}\text { Vicat softening, }{ }^{0} \mathrm{C} \\
\text { Point, }{ }^{\circ} \mathrm{C}\end{array}$ & $\begin{array}{c}\text { MFI, g/10 } \\
\text { min }\end{array}$ \\
\hline $50 / 50 / 0$ & 13.15 & 20 & 160 & 9.5 \\
\hline $50 / 50 / 0.5$ & 16.87 & 24 & 160 & 13.8 \\
\hline $50 / 50 / 1.0$ & 14.96 & 24 & 160 & 18.5 \\
\hline $50 / 50 / 2.0$ & 13.83 & 22 & 160 & 25.4 \\
\hline
\end{tabular}

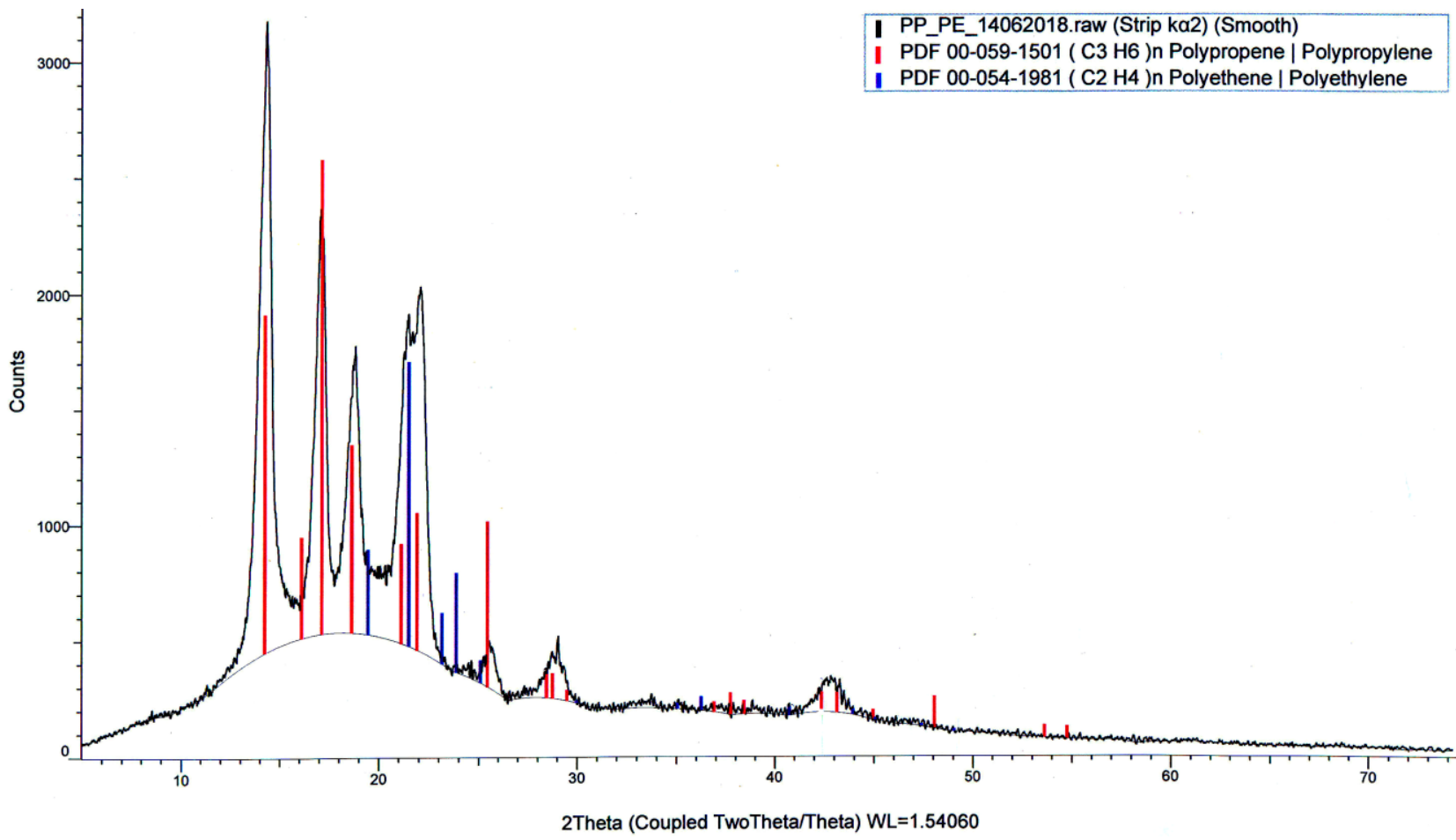

Fig.1. Diffractogram of the sample PP/PE.

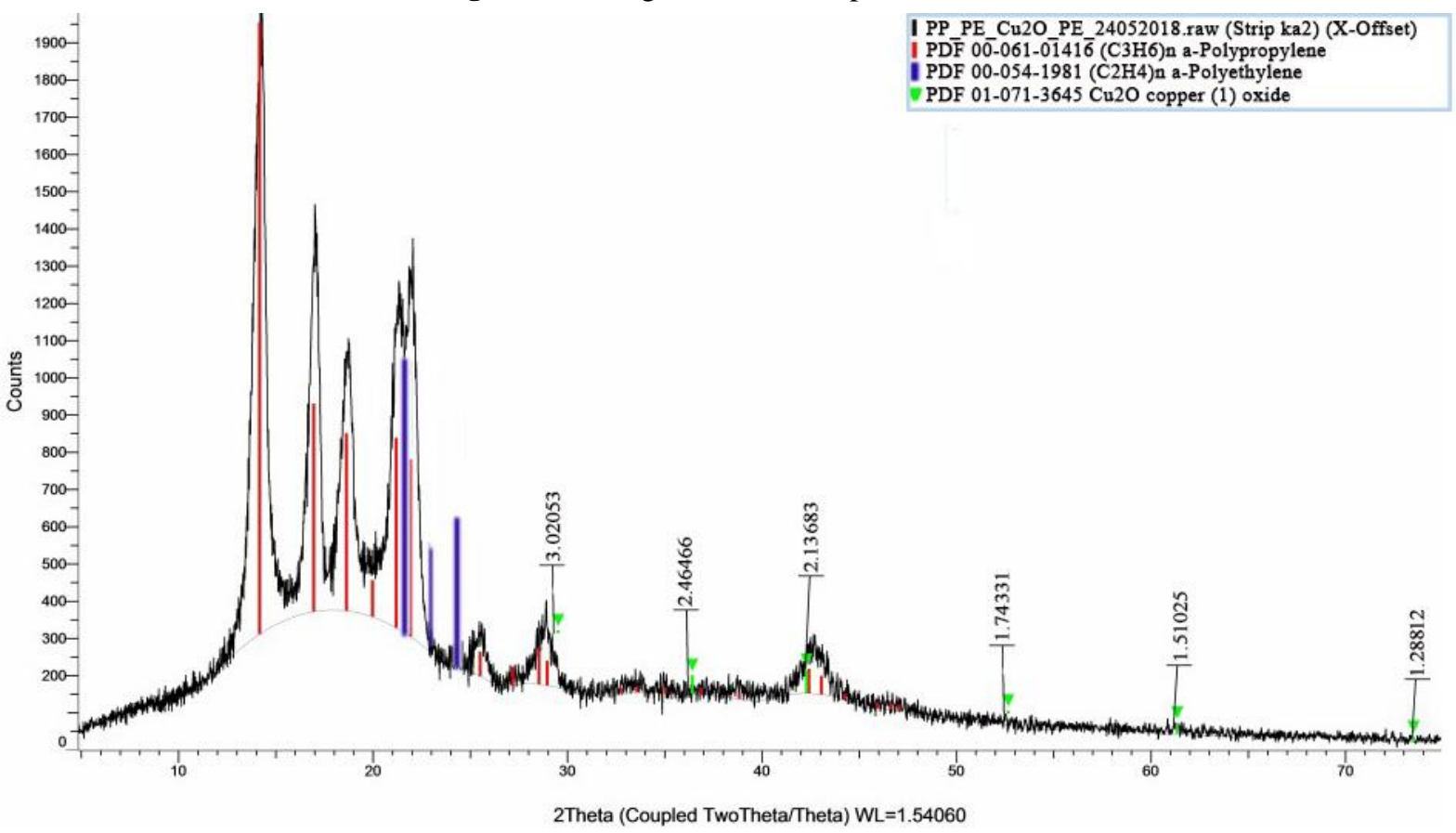

Fig.2. Diffractogram of the sample PP/PE/NF. 
Table 2. Thermal properties of studied nanocomposites samples

\begin{tabular}{|c|c|c|c|c|c|}
\hline $\begin{array}{c}\text { Composition, mass. \% } \\
\text { PP/PE/NF }\end{array}$ & $T_{10}{ }^{0} \mathrm{C}$ & $T_{20},{ }^{0} \mathrm{C}$ & $T_{50},{ }^{0} \mathrm{C}$ & $\tau_{1 / 2}, \min$ & $E_{\mathrm{a},} \mathrm{kJ} / \mathrm{mol}$ \\
\hline $50 / 50 / 0$ & 200 & 275 & 325 & 55.6 & 191.4 \\
\hline $50 / 50 / 0.5$ & 300 & 335 & 380 & 71.2 & 230.5 \\
\hline $50 / 50 / 1.0$ & 335 & 355 & 390 & 74.8 & 248.9 \\
\hline $50 / 50 / 2.0$ & 290 & 320 & 360 & 69.1 & 220.7 \\
\hline
\end{tabular}

Derivatographic studies have shown that the introduction of NF containing NP of copper oxides into the composition improves the thermal-oxidative stability of the obtained nanocomposites.

Numerous experimental data on the mechanical, strength, relaxation, and other properties of polymer-polymer, polymer-filler mixtures are explained in within a frame of concepts on existence of interphase layer [17].

The properties of polymer composites are significantly affected by the supramolecular structure of the polymer (the size of spherulites, the degree of crystallinity, the presence of $\mathrm{C}=\mathrm{O}$ groups, different branchings, etc.) the interfacial interaction at the phase boundary [18].

The copper-containing nanoparticles used in this work, located at the interface between the structural elements of PP and PE, contribute to the formation of heterogeneous nucleation centers in the composition of the melt, which, in the process of stepwise cooling of the nanocomposite, contribute to the increase of crystallization centers, which generally lead to an improvement in the crystallization process and the formation of a relatively fine spherulite structure.

The results testify to that small amounts of nanofiller (0.5-1.0 mass \%) introduced into the polymer obviously play the role of structure-forming agents - artificial crystallization nuclei, which contributes to the formation of a fine-spherulite structure in the polymer, characterized by improved physical-mechanical, rheological and thermal properties of the resulting nanocomposite [19].

\section{Conclusion}

The effect of a nanofiller containing copper oxide nanoparticles stabilized by a polyethylene matrix obtained by the mechanochemical method on composites properties based on $\mathrm{PP} / \mathrm{PE}$ is studied.
X-ray diffraction patterns confirm the presence of copper oxide nanoparticles in the composition of PP/PE based composites

The improvement of strength, deformation and rheological indicators, as well as thermo-oxidative stability of the obtained nanocomposites was revealed.

It is shown that PP/PE based nanocomposites can be processed both by pressing and by injection molding and extrusion.

The prospects of using a nanofiller containing NP of copper oxides stabilized by a polyethylene matrix obtained by the mechanochemical method as an additive to PP/PE has been shown, which contributes to the creation of a fine-crystalline structure of the composition, and therefore its properties are improved and thereby the field of application of the obtained nanocomposite is expanded.

\section{References}

1. Ermakov S.N., Kravchenko T.P. Polymer compatibility. Thermodynamic and chemical aspects. Plast. Mass. 2012. No. 4. P. 32-38.

2. Novokshonov V.V., Musin I.N., Kimbelblat V.I. Dependence of the properties of PP/EPR mixtures on the composition and characteristics of polymers. Plast. mass. 2009. No 5. P. 7-10.

3. Kuchmenova L.Kh., Slonov A.L., Zhansitov A.A., Shelgaev V.N., Khashirova S.Yu., Mikitaev A.K. The study of the thermal properties of polymerpolymer compositions based on PP. Plast. mass. 2014. No 7-8. P. 7-9.

4. Nigmatulina A.I, Vol'fson S.I., Okhotina N.A., Shaldybina M.S. Svoystva dinamicheskikh termoelastoplastov, soderzhashchiy modifitsirovannyy polipropilen i sloistyy napolnitel'. Vestn. Kazan. tekhnol. un-ta. 2010. № .9. S. 329-331.

5. Perestoronina Z.A., Ableyev R.I., Baranets I.V., Kurlyand S.K. Vliyaniye polimernykh dobavok na usileniye mezhfaznogo vzaimodeystviya v smesevykh termoelastoplastakh. Kauchuk i rezina. 2012. № 2. S. 13-16.

6. Zaikin A.Ye., Bobrov G.B. Maslostoykiy termoelastoplast na osnove smesi polipropilena i sopolimeraetilena s vinilatsetatom, vulkanizirovannyy 
po reaktsii gidrosililirovaniya. Vest. Kazan. Tekhnol. un-ta. 2013. T. 16. № 2. S. 105-108.

7. Kakhramanov N.T., Guliyev A.D., Pesetskiy S.S. Dinamicheski vulkanizovannyye nanokompozity na osnove random poliproplena, butadiyen-nitril'nogo kauchuka i kaolina. Kompozity i nanostruktury. 2019. № 4. S. 131- 136.

8. Sevastyanov D.V., Doriomedov M.S., Daskovsky M.I., Skripachev S.Yu. Self-reinforced polymer composites classification, preparation, mechanical properties and applications (review). Electronic scientific journal "VIAM Works". 2017. No 4. P. 104-118.

9. Mikhaylin Yu.A. Polymer nanocomposite materials. Polymer materials. 2009. No 7. P. 10-13.

10. Tretyakov A.O. Polymer nanocomposites are materials of the 21st century. Equipment and tools for professionals. 2003. No 2 (37). P. 18-20

11. Foster L. Nanotechnology. Science, innovation and opportunity. M.: Technosphere, 2008. 352 p.

12. Pomogailo A.D., Rosenberg A. S., Uflyand I. E. Metal nanoparticles in polymers. M.: Chemistry, 2000. 672 p.

13. Gubin S.P., Yurkov G.Yu., Kosobudsky I.D. Nanomaterials based on metal-containing nanoparticles in polyethylene and other carbon-chain polymers. Int. J. Materials and Product Technology. 2005. V. 23. № 1-2. P. 2-25.
14. Kurbanova N.I., Kuliyev A.M., Alimirzoeva N.A., Aliyev A.T., Ishenko N.Ya., Nurullayeva D.R. Preparation of copper-containing nanoparticles in polyethylene matrix without use of solvents. Science and Technology of Polymers and Advanced Materials: Applied Research Methods. Editor(s):O.V. Mukbanıanı, T.N. Tatrıshvılı, M.J.M. Abadie to be published by Apple Academic Press, 2019. P. 57-65.

15. Ragimova S.K. Obtaining the metal-containing nanoparticles in polyethylene matrix by mechanochemical method and study of their properties. Azerb. Chem. J. 2020. No 2. P. 20-25.

16. Tekhnicheskiye svoystva polimernykh materialov: Uchebno-spravochnoye posobiye. Pod obshchey red. prof. V.K. Kryzhanovskogo. SPb: Professiya, 2007. $240 \mathrm{~s}$

17. Pomogailo A.D. Molecular polymer-polymer compositions. Synthetic aspects. Advances in chemistry. 2002. V. 71. № 1. P. 5-38.

18. Kuleznev V.N. Smesi i splavy polimerov. Konspekt lektsiy. SPb.: Nauchnyye osnovy i technologii. 2013. $216 \mathrm{~s}$.

19. Kakhramanly Yu.N. Nesovmestimyye polimernyye smesi i kompozitsionnyye materialy na ikh osnove. Baku: Elm, 2013. 152 s.

\title{
IZOTAKTIK POLIIPROPILEN VO YÜKSӘK TOZYIQLII POLIETILEN OSASINDA MISTəRKIBLI NANOKOMPOZITLOR
}

\begin{abstract}
S.K.Rəhimova
Mexaniki-kimyəvi üsulla alınmış polietilen matrisində stabilləşdirilmiş mis oksid nanohissəcikləri (NH) saxlayan nanodoldurucuların (ND) izotaktik polipropilen(PP) və yüksək təzyiqli polietilen (PE) əsasında nanokompozitlərin xassələrinə təsiri rentgenfaza (RFA) və termoqravimetrik analiz (TQA) metodları ilə tədqiq olunmuşdur. Alınan nanokompozitlərin möhkəmlik, deformasiya və reoloji xassələrinin, həmçinin termooksidləşmə stabilliyinin yaxş1laşması müəyyən edilmişdir. Görünür, bu da yüksək təzyiq polietilenindəki mistərkibli nanohissəciklərin PP/PE kompozitin komponentləri ilə qarşılıqlı təsirinin sinergetik effekti ilə əlaqədardır.
\end{abstract}

Açar sözlər: izotaktik polipropilen, yüksək təzyiqli polietilen, mis oksid nanohissaciklori, termiki xassalar, RFA, TQA analizi.

\section{МЕДЬСОДЕРЖАЩИЕ НАНОКОМПОЗИТЫ НА ОСНОВЕ ИЗОТАКТИЧЕСКОГО ПОЛИПРОПИЛЕНА И ПОЛИЭТИЛЕНА ВЫСОКОГО ДАВЛЕНИЯ}

\section{С.К.Рагимова}

Исследовано влияние добавок нанонаполнителей (НH), содержащих наночастицы оксидов меди, стабилизированные полимерной матрицей полиэтилена высокого давления, полученные механо-химическим методом, на особенности структуры и свойств металлсодержащих нанокомпозитов на основе изотактического полипропилена и полиэтилена высокого давления методами дифференциально-термического (ДТА) и рентгенфазового (РФА) анализов. Выявлено улучшение прочностных, деформационных и реологических показателей, а также термоокислительной стабильности полученных нанокомпозитов, что, по-видимому, связано с синергетическим эффектом межфазного взаимодействия медьсодержащих наночастиц в матрице ПЭ с компонентами полимерной композиции ПП/ПЭ.

Ключевые слова: изотактический полипропилен; полиэтилен высокого давления; наночастицы оксидов меди; термические свойства, ДТА и РФА анализы. 